\title{
Review of a Challenging Clinical Issue: Acute Biliary Pancreatitis During Pregnancy
}

\section{Zorlu Bir Klinik Sorunun Gözden Geçirilmesi: Gebelikte Akut Biliyer Pankreatit}

\section{(D) Yasin Ceylan 1 , (D) Bertan Akar²}

${ }^{1}$ University of Health Sciences Turkey, İstanbul Bağcılar Training and Research Hospital, Clinic of Obstetrics and Gynecology, İstanbul, Turkey 2İstinye University Faculty of Medicine; Private Kocaeli Hospital, Clinic of Obstetrics and Gynecology, İstanbul, Kocaeli, Turkey

\section{Abstract}

Acute pancreatitis is an inflammatory condition of the pancreas most commonly caused by gallstone. Approximately $70 \%$ cases of acute pancreatitis during pregnancy are secondary to gallstones or sludge. Acute pancreatitis is a rare complication with a reported incidence of one per 1.500-4.500 pregnancies. Gallstones cause bile duct obstruction and pancreatic hyperstimulation. These processes lead to increased hydrostatic pressure, trypsin reflux and activation of digestive enzymes within the pancreas and cause autodigestion of pancreas, followed by local inflammation. During pregnancy, the steroid hormones of pregnancy affect the gallbladder motility and bile content. Progesterone induces gallbladder smooth muscle relaxation and estrogens increase bile cholesterol level, enhancing bile stasis. The clinical symptoms include pain in the right upper abdominal area and/or epigastric area, which can radiate to the right flank, scapula and shoulder, anorexia, nausea, vomiting, dyspepsia, low-grade fever and sinus tachycardia, hyperventilation and smell of acetone in the breath. The diagnosis of acute pancreatitis in pregnancy is confirmed by laboratory investigations and imaging methods. The management of acute biliary pancreatitis during pregnancy is similar on a large scale.

Keywords: Acute biliary pancreatitis, pancreatitis, pancreatitis during pregnancy

\section{Öz}

Akut pankreatit, en yaygın olarak safra taşının neden olduğu pankreasın iltihaplı bir durumudur. Hamilelik sırasında akut pankreatit olgularının yaklaşık \%70'i safra taşı veya çamura ikincildir. Akut pankreatit, 1,500-4,500 gebelikte bir bildirilen insidansı ile nadir bir komplikasyondur. Safra taşları safra kanalı tıkanıklığına ve pankreas hiperstimülasyonuna neden olur. Bu süreçler, hidrostatik basıncı, tripsin geri akışını ve pankreas içindeki sindirim enzimlerinin aktivasyonunu artırarak pankreasın kendi kendine sindirilmesine ve ardından lokal iltihaplanmaya neden olur. Hamilelik sırasında, hamileliğin steroid hormonları safra kesesi hareketliliğini ve safra içeriğini etkiler. Progesteron safra kesesi düz kas gevşemesine neden olur ve östrojenler safra kolesterol seviyesini yükselterek safra stazını artııı. Klinik semptomlar arasında sağ üst karın bölgesinde ve/ veya epigastrik bölgede ağrı, sağ flank, skapula ve omuza yayılabilen ağrı, iştahsızlık, bulantı, kusma, dispepsi, düşük dereceli ateş ve sinüs taşikardisi, hiperventilasyon ve nefesin aseton kokusu yer alır. Gebelikte akut pankreatit tanısı, laboratuvar incelemeleri ve görüntüleme yöntemleri ile doğrulanır. Gebelik sırasında akut biliyer pankreatitin yönetimi büyük ölçüde benzerdir.

Anahtar kelimeler: Akut bilier pankreatit, gebelik sırasında pankreatit, pankreatit

\section{Introduction}

The prevalence rate of gallstones varies with ethnicity. The incidence is higher in Native American Indians, Mexicans and Latin Americans but lower in Asia and Africa (1).
Gallbladder disease is closely related to the metabolic syndrome. Pregnancy is an important risk factor for gallbladder disease. Hormonal changes and weight gain are major risk factors for biliary sludge and gallstone formation during pregnancy (2). 
Acute pancreatitis is a rare complication with a reported incidence of one per 1.500-4.500 pregnancies $(3,4)$. Acute pancreatitis is a dangerous disease with high maternal and fetal mortality rates. Over the past decade, the maternal and fetal mortality rates were $37 \%$ and 11 to $37 \%$, respectively. However, maternal mortality declined to $<1 \%$ and perinatal mortality was nearly $18 \%$ in recent studies. Approximately $70 \%$ of cases of acute pancreatitis during pregnancy are secondary to gallstones or sludge (5).

\section{Pathogenesis}

Gallstones cause bile duct obstruction and pancreatic hyperstimulation. These processes lead to increased hydrostatic pressure, trypsin reflux and activation of digestive enzymes within the pancreas and cause autodigestion of pancreas, followed by local inflammation (6).

The reasons for the association of pregnancy and biliary tract disease include increased volume of the gallbladder and decreased flow of bile (7). During pregnancy, the steroid hormones of pregnancy affect the gallbladder motility and bile content. Progesterone induces gallbladder smooth muscle relaxation and estrogens increase bile cholesterol level, enhancing bile stasis (8).

High parity is a risk factor for gallstones; however, it remains unclear (9). Pre-pregnancy body mass index (BMI) is a strong predictor factor of gallbladder diseases. Obesity $\left(B M I>30 \mathrm{~kg} / \mathrm{m}^{2}\right)$ is strongly associated with gallbladder diseases. However, weight gain during pregnancy is conversely associated with the risk of incident gallbladder diseases (10).

Insulin resistance increases the risk of gallstones and sludge, which is another situation associated with obesity (11). Some studies report that women gain more weight during pregnancy and this weight could contribute to insulin resistance (10).

Serum leptin level is another predictive factor of gallbladder disease. Leptin is a hormone which is secreted by the adipose tissue and closely correlated with body fat mass. Leptin levels are increased during pregnancy. Leptin affects biliary cholesterol elimination and may cause gallstone formation and gallbladder disease $(12,13)$.

\section{Clinical Presentation}

The symptoms of acute pancreatitis due to the gallbladder disorders in pregnancy are non-specific. The symptoms of gallbladder disease can be present before the clinical presentation of acute pancreatitis. The symptoms include the classic colicky or stabbing pain in the right upper abdominal area and/or epigastric area, which can radiate to the right flank, scapula and shoulder in about $40 \%$ of cases. Other symptoms are anorexia, nausea, vomiting, dyspepsia, low-grade fever and sinus tachycardia, hyperventilation and smell of acetone in the breath. Abdominal pain due to the acute pancreatitis could be mild to severe with abdominal tenderness, muscle rigidity, jaundice, paralytic ileus and hypoxemia. The symptoms can occur at any time of pregnancy but increase with gestational age. The duration of symptoms may change from 24 hours up to 3 weeks.

\section{Diagnosis}

The diagnosis of acute pancreatitis in pregnancy is confirmed by laboratory investigations and imaging methods. Serum amylase and lipase levels could be elevated three times over upper limit of normal value. Serum glucose, bilirubin and liver enzyme activities could be normal or increased. Leukocytosis may be present (14).

Abdominal ultrasound scan with no radiation to the fetus is an initial, safe and inexpensive imaging technique for the detection of gallstones, which are a potential cause of acute pancreatitis in pregnancy (15).

Magnetic resonance cholangiopancreatography (MRCP) provides multi-planar large field with excellent soft-tissue contrast and images of bilio-pancreatic duct systems. MRCP does not require contrast medium and radiate ionizing radiation to mother and fetus. The sensitivity of MRCP to the diagnosis of common bile duct stones is over $90 \%$ (15). It could also specify their numbers and locations but small gallstones located in the distal common bile duct could be missed by MRCP (16). The other advantage of MRCP is also its facilitating endoscopic retrograde cholangiopancreatography (ERCP) and laparoscopic cholecystectomy (17).

Endoscopic ultrasonography (EUS) has higher specificity than MRCP in detecting suspected small common bile duct stones $(\leq 2 \mathrm{~mm}$ ) or sludge. However, EUS requires general anesthesia and expensive equipment, and depends on the operator's experience (18).

Although computed tomography is the most commonly used imaging technique in the diagnosis of acute pancreatitis among adults, it is not recommended in pregnant patients because of the fear of radiation exposure of the fetus (19).

ERCP is used for both diagnostic and therapeutic options in selected acute biliary pancreatitis cases when other 
imaging techniques fail to demonstrate small gallstones or sludge in the common bile duct (20). ERCP with endoscopic sphincterotomy is useful in extracting small gallstones and ensuring the drainage of the infected bile in severe acute biliary pancreatitis (21). A major concern for this procedure has been radiation exposure of the fetus. Therefore, before performing therapeutic ERCP, MRCP or EUS helps to identify patients who require ERCP (22).

\section{Treatment}

The management of acute biliary pancreatitis during pregnancy is similar on a large scale. The pregnant women should be admitted to an intensive care unit. Intravenous fluid and nutritional therapy are required. Parenteral nutrition outcomes are successful in obstetric patients. However, the frequency of central venous catheter- related complications are higher in pregnant than in non-pregnant patients (23). Naso-jejunal enteral nutrition is preferable to total parenteral nutrition in severe acute pancreatitis during pregnancy. Enteral nutrition has lower frequency of infectious complications than parenteral nutrition (24).

The first decision is a choice of which procedure to clear gallstones in common bile duct. The second decision is cholecystectomy time (25). The presence or absence of common bile duct dilatation, cholangitis, obstructive jaundice, peritonitis, severity of acute pancreatitis and trimester of pregnancy affect the treatment modalities. Although symptomatic biliary tract diseases are managed conservatively, $50 \%$ of patients receiving conservative treatment have recurrent episodes of biliary pancreatitis during pregnancy (4). Acute biliary pancreatitis patients could be evaluated for cholecystectomy to prevent recurrence during pregnancy. Laparoscopic cholecystectomy is a safe procedure for both the mother and the fetus in all trimesters (26). It cannot be performed at late gestation weeks because uterus is too big and it makes difficult to evaluate the surgical area for laparoscopic approach. The main advantages of laparoscopic cholecystectomy are earlier mobilization, shorter hospitalization time, lower dose of narcotic and analgesic use, lower risk of wound infections and thromboembolism (27). Uterine injuries during trocar placement, preterm delivery and fetal acidosis are the main complications of laparoscopic cholecystectomy (28).

ERCP is another safe and alternative diagnostic and therapeutic procedure in acute biliary pancreatitis during pregnancy. Sphincterotomy and clearance of bile duct stones by ERCP are indicated in patients with severe acute pancreatitis, cholangitis and persistent biliary obstruction
(29). Biliary sphincterotomy with ERCP may be more suitable than cholecystectomy in acute biliary pancreatitis during pregnancy (30).

\section{Conclusion}

Acute pancreatitis is a dangerous disease with high maternal and fetal mortality rates. The diagnosis of acute pancreatitis in pregnancy is confirmed by laboratory investigations and imaging methods. The management of acute biliary pancreatitis during pregnancy is similar on a large scale.

\section{Ethic}

Peer-review: Internally peer-reviewed.

\section{Authorship Contributions}

Concept: Y.C., Design: B.A., Data Collection or Processing: Y.C., Analysis or Interpretation: B.A., Literature Search: B.A., Writing: Y.C.

Conflict of Interest: No conflict of interest was declared by the authors.

Financial Disclosure: The authors declared that this study received no financial support.

\section{References}

1. Singh V, Trikha B, Nain C, Singh K, Bose S. Epidemiology of gallstone disease in Chandigarh: a community-based study. J Gastroenterol Hepatol 2001;16(5):560-563.

2. Stampfer MJ, Maclure KM, Colditz GA, Manson JE, Willett WC. Risk of symptomatic gallstones in women with severe obesity. Am J Clin Nutr 1992;55(3):652-658.

3. Eddy JJ, Gideonsen MD, Song JY, Grobman WA, O'Halloran P. Pancreatitis in pregnancy. Obstet Gynecol 2008;112(5):1075-1081.

4. Hernandez A, Petrov MS, Brooks DC, Banks PA, Ashley SW, Tavakkolizadeh A. Acute pancreatitis and pregnancy: a 10-year single center experience. J Gastrointest Surg 2007;11(12):16231627.

5. Papadakis EP, Sarigianni M, Mikhailidis DP, Mamopoulos A, Karagiannis V. Acute pancreatitis in pregnancy: an overview. Eur J Obstet Gynecol Reprod Biol 2011;159(2):261-266.

6. Vonlaufen A, Wilson JS, Apte MV. Molecular mechanisms of pancreatitis: current opinion. J Gastroenterol Hepatol 2008;23(9):1339-1348.

7. Everson GT, McKinley C, Lawson M, Johnson M, Kern F Jr. Gallbladder function in the human female: effect of the ovulatory cycle, pregnancy, and contraceptive steroids. Gastroenterology 1982;82(4):711-719.

8. Ramin KD, Ramsey PS. Disease of the gallbladder and pancreas in pregnancy. Obstet Gynecol Clin North Am 2001;28(3):571-580.

9. Basso L, McCollum PT, Darling MR, Tocchi A, Tanner WA. A study of cholelithiasis during pregnancy and its relationship 
with age, parity, menarche, breast-feeding, dysmenorrhea, oral contraception and a maternal history of cholelithiasis. Surg Gynecol Obstet 1992;175(1):41-46.

10. Ko CW, Beresford SA, Schulte SJ, Matsumoto AM, Lee SP. Incidence, natural history, and risk factors for biliary sludge and stones during pregnancy. Hepatology 2005;41(2):359-365.

11. Ko CW, Beresford SA, Schulte SJ, Lee SP. Insulin resistance and incident gallbladder disease in pregnancy. Clin Gastroenterol Hepatol 2008;6(1):76-81.

12. Méndez-Sánchez N, González V, King-Martínez AC, Sánchez $\mathrm{H}$, Uribe M. Plasma leptin and the cholesterol saturation of bile are correlated in obese women after weight loss. J Nutr 2002;132(8):2195-2198.

13. VanPatten S, Ranginani N, Shefer S, Nguyen LB, Rossetti L, Cohen DE. Impaired biliary lipid secretion in obese Zucker rats: leptin promotes hepatic cholesterol clearance. Am J Physiol Gastrointest Liver Physiol 2001;281(2):G393-G404.

14. Ramin KD, Ramin SM, Richey SD, Cunningham FG. Acute pancreatitis in pregnancy. Am J Obstet Gynecol 1995;173(1):187191.

15. Roumieu F, Ponchon T, Audra P, Gaucherand P. Acute pancreatitis in pregnancy: place of the different explorations (magnetic resonance cholangiopancreatography, endoscopic ultrasonography) and their therapeutic consequences. Eur J Obstet Gynecol Reprod Biol 2008;140(1):141-142.

16. Scheiman JM, Carlos RC, Barnett JL, Elta GH, Nostrant TT, Chey $\mathrm{WD}$, et al. Can endoscopic ultrasound or magnetic resonance cholangiopancreatography replace ERCP in patients with suspected biliary disease? A prospective trial and cost analysis. Am J Gastroenterol 2001;96(10):2900-2904.

17. Polydorou A, Karapanos K, Vezakis A, Melemeni A, Koutoulidis V, Polymeneas G, et al. A multimodal approach to acute biliary pancreatitis during pregnancy: A case series. Surg Laparosc Endosc Percutan Tech 2012;22(5):429-432.

18. Pitchumoni CS, Yegneswaran B. Acute pancreatitis in pregnancy. World J Gastroenterol 2009;15(45):5641-5646.

19. Kennedy A. Assessment of acute abdominal pain in the pregnant patient. Semin ultrasound CT MR. 2000;21(1):64-77.
20. Turhan AN, Gönenç M, Kapan S, Islim F, Oner OZ, Tulubaş E, et al. Acute biliary pancreatitis related with pregnancy: a 5-year single center experience. Ulus Travma Acil Cerrahi Derg 2010;16:160-164.

21. NIH state-of-the-science statement on endoscopic retrograde cholangiopancreatography (ERCP) for diagnosis and therapy. NIH Consens State Sci Statements 2002;19(1):1-26.

22. Ainsworth AP, Rafaelsen SR, Wamberg PA, Durup J, Pless TK, Mortensen MB. Is there a difference in diagnostic accuracy and clinical impact between endoscopic ultrasonography and magnetic resonance cholangiopancreatography? Endoscopy 2003;35(12):1029-1032.

23. Russo-Stieglitz KE, Levine AB, Wagner BA, Armenti VT. Pregnancy outcome in patients requiring parenteral nutrition. J Matern Fetal Med 1999;8(4):164-167.

24. Petrov MS, Whelan K. Comparison of complications attributable to enteral and parenteral nutrition in predicted severe acute pancreatitis: a systematic review and meta-analysis. Br J Nutr 2010;103(9):1287-1295.

25. Carr-Locke DL. Cholelithiasis plus choledocholithiasis: ERCP first, what next? Gastroenterology 2006;130(1):270-272.

26. Date RS, Kaushal M, Ramesh A. A review of the management of gallstone disease and its complications in pregnancy. Am J Surg 2008;196(4):599-608.

27. Jackson H, Granger S, Price R, Rollins M, Earle D, Richardson W, et al. Diagnosis and laparoscopic treatment of surgical diseases during pregnancy: an evidence-based review. Surg Endosc 2008;22(9):1917-1927.

28. Palanivelu C, Rangarajan M, Senthilkumaran S, Parthasarathi R. Safety and efficacy of laparoscopic surgery in pregnancy: experience of a single institution. J Laparoendosc Adv Surg Tech A 2007;17(2):186-190.

29. Banks PA, Freeman ML; Practice Parameters Committee of the American College of Gastroenterology. Practice guidelines in acute pancreatitis. Am J Gastroenterol 2006;101(10):2379-2400.

30. Baillie J, Cairns SR, Putman WS, Cotton PB. Endoscopic management of choledocholithiasis during pregnancy. Surg Gynecol Obstet 1990;171(1):1-4. 